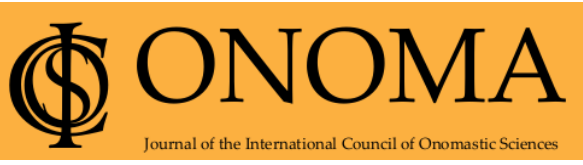

Onoma 56

Journal of the International Council of Onomastic Sciences

ISSN: 0078-463X; e-ISSN: 1783-1644

Journal homepage: https://onomajournal.org/

\title{
Allison Dollimore \& Peter Jordan (eds.), Place names and migration. Proceedings of the Symposium in Vienna, 6-8 November 2019, 2021, 283 pp., Hamburg: Verlag Dr. Kovač, ISBN 978-3-339-11844-8
}

\section{Helen Kerfoot ${ }^{*}$}

Ottawa, Canada

To cite this article: Kerfoot, Helen. 2021. Allison Dollimore \& Peter Jordan (eds.), Place names and migration. Proceedings of the Symposium in Vienna, 6-8 November 2019, 2021, 283 pp., Hamburg: Verlag Dr. Kovač, ISBN 978-3-33911844-8. Onoma 56, 317-321. DOI: 10.34158/ONOMA.56/2021/19

To link to this article: https://doi.org/10.34158/ONOMA.56/2021/19

(C) Onoma and the author.

\section{Article history}

Received on 22 June 2021.

Final form accepted on 12 December 2021.

Published online on 13 December 2021. 


\section{Allison Dollimore \& Peter Jordan (eds.), Place names and migration. Proceedings of the Symposium in Vienna, 6-8 November 2019, 2021, 283 pp., Hamburg: Verlag Dr. Kovač, ISBN 978-3-339-11844-8}

HELEN KERFOOT

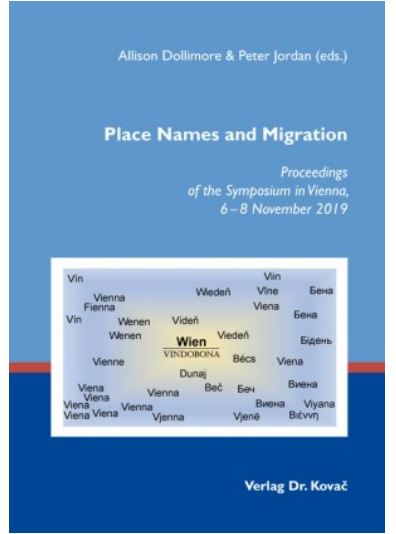

(https://www.verlagdrkovac. de/978-3-339-11844-8. htm\#pop11844)
Geographical names have power as they embody our history and our relationship to space. Over the decades and centuries, they have been subject to change - one reason being that in many places migration in various forms produced layers of sequential toponyms. Some are well known today, others that have been altered or erased from current use can still provide a window on history.

To provide a forum to discuss place names and migration a symposium was held in Vienna, 6-8 November 2019, in conjunction with celebration of the 50th anniversary of the Austrian Board on Geographical Names (AKO). The event was jointly organised by $\mathrm{AKO}$, the Dutch- and German-speaking

Division of the United Nations Group of Experts on Geographical Names (UNGEGN), the Austrian Federal Office of Metrology and Surveying (BEV), the Austrian Geographical Society (OGC) and the Joint ICA/IGU Commission on Toponymy (co-chaired by Peter Jordan and Cosimo Palagiano). On this occasion 26 papers were presented from 16 countries in five continents. Of these, 18 are included in the proceedings that appear under the auspices of the International Cartographic Association (ICA) and the International Geographical Union (IGU), which together covered the production costs. This 283-page collection of papers, Place names and migration, is volume 9 of Name \& Place, contributions to toponymic literature and research, a series initiated in 2011.

The papers are presented in three sections:

1. The research field and trans-continental contacts (4 papers):

- Jordan, Peter. "Place names and migration" as a research field;

- Ormeling, Ferjan. Dutch names worldwide: the naming behaviour of Dutch explorers in the 17th and 18th centuries;

- Louati, Fatima; Bouhadjer, Souad. A diachronic study of Phoenician place names in the Middle East and North Africa; 
- Palagiano, Cosimo; Capuzzo, Ester. The transfer of place names from Italy to Latin America.

2. Extra-European situations (5 papers):

- Choo, Sungjae; Yoon, Jihwan. A case of the impelled migration before and during the Korean War;

- Liščák, Vladmir. Han immigration to Taiwan since the 17th century and changes in place names;

- Huang, Wenchuan. Street names embodying colonial legacy and spatial politics in Hong Kong;

- Kang, Peter. Hokkien toponyms used by Hokkien immigrants in Batavia, Java: Cases from 18th and 19th centuries;

- Matthews, Philip. The consequences of British colonization for geonames in New Zealand.

3. European situations ( 9 papers):

- Lucarno, Guido; Bacher, Valeria; Bacher, Annamaria. Toponymy of Walser immigration in the Italian Alps since the 13th century. A survey in the Formezza Valley;

- Pohl, Heinz-Dieter. Slovenian place names in Carinthia and East Tyrol;

- Włoskowicz, Wojciech. Migrations as the cause of diachronic toponymic layers in the Polish Beskids;

- Sasi, Attila; Mikesy, Gábor. The Pannonian Basin at the crossroads of peoples;

- Manu, Margareta Magda. Ethnonyms used for and by Romanian migrant groups in Transylvania and their reflections in toponymy;

- Felecan, Oliviu. Romanian unofficial urban toponyms related to recent migration;

- Mácha, Přemysl. Migrants and migration in the linguistic landscape of Brno, Czechia;

- Crljenko, Ivana. Traces of Croatian migrations in the toponymy of several European countries;

- Herzen, Andrey. The historical-geographical context of transferred toponyms.

Migration is a global phenomenon, unrestricted by time or space, as groups or individuals move and must adapt to their new surroundings. Place names in this context are approached in this book both synchronically and diachronically. How migrants deal with place names - accepting them, adapting them or creating new names - is addressed by the authors' contributions.

Peter Jordan, in his introductory article cites works relevant to toponymic research and migration and puts the book contributions into perspective. They can be grouped under different aspects of migrant situations and associations: 
(1) Names used by migrants from a dominant political power. Colonisers, traders and migrants often impose names or adapt existing names to their languages. Ormeling writes of Dutch explorers, who in some cases became colonisers, either adapting existing names to the Dutch language or coining new names (often for their home towns). Matthews elaborates on the impact of British colonisers putting their stamp on names of geographical features in New Zealand. Huang discusses the street names of Hong Kong where some significant streets and squares still recall the British colonial era with commemorative names. Louati and Bouhadjer indicate the influence of Phoenicians as traders who built ports on the Mediterranean and developed a wide commercial network; their influence is still seen in toponyms of the Middle East and North Africa.

(2) Names used by migrants not associated with political power. Migrants lacking political power or social superiority appear most often to use existing endonyms, although groups migrating within the language area may use dialectal forms identifying their smaller groups. Such findings are noted by Mácha in Brno and by Felecan in Romanian cities, except for new shops and restaurants opened by migrants using their own language, creating more exotic names to attract customers. Crljenko tells of Croatian migrants, who individually had little influence on the namescape, but as compact groups see many of their place names now official as minority rights have improved. Lucarno et al write about the Waiser communities of farmers from the 13th century settling in the high Italian Alps, where although the oral traditions are lost some Waiser names remain as minority language forms.

(3) Migrants repeating the names of their places of origin. Preserving emotional ties with the mother country is a common naming procedure of immigrants in the New World. Palagiano and Capuzzo refer to Italians who had emigrated to Latin America, and named features to encourage further immigrants, despite sometimes luring them to a bleak location. Liščák describes how waves of Chinese Han immigrants to Taiwan since the 17th century named features based on their first impressions and their relationship to previous life experiences. Herzen implies transfer of place names by migrants from southwest Serbia to the middle Dniester in the Republic of Moldova.

(4) Migrants creating new names. Among the common naming processes is the use of commemorative names of leaders and events. Choo and Yoon write of Korean migrants from North to South Korea between 1945 and 1953 trying to preserve their identity by using names that characterised their feelings and intentions. Kang highlights the names used by Hokkien immigrants from China to Batavia that describe the functioning of places, often representing the phonetics of existing names with their own orthography.

(5) Naming practices of host societies for migrant places. In recent times host societies may use "Chinatown" or "Little Italy" in urban settings, but such names rarely achieve official status. However, Manu illustrates that 
in Romania names of places after migrant communities who settled there earlier have been standardised and made official.

(6) Place names as keys to migration history. Research on the connection of toponyms to migration and settlement history has been widely published. Some contributions to the field are included in this book. Pohl enlarges on previous toponymic studies of migrant settlement in Carinthia to include East Tyrol. Włoskowicz uses similar methods in tracing the use of place names by groups of transhumance Vlach shepherds in Polish Beskydy in the Middle Ages. Sasi and Mikesy analyse the migration history of the Pannonian Basin, finding the migration waves had various kinds of naming practices - preserving, translating, adapting and creating new names. Herzen identifies toponyms in the middle Dneister region of Moldavia, proving historical migration from Raška in southwest Siberia.

Although migration "begins with a physical relocation of human beings, it does essentially include the movement of culture, history, language and lifestyles" (Choo \& Yoon 2021: 71). As shown in several articles unofficial migrant-introduced toponyms may exist side by side with existing names, forming a parallel (but usually unequal) system that is "correlated with social evolution and development" (Felecan 2021: 229). Using their own language forms makes migrants feel more comfortable in their environment and creates for them a collective identity.

All articles refer to the namescape or the linguistic landscape, a powerful concept that "can fruitfully be applied to integration of migrant communities into host societies" (Mácha 2021: 239). In this book, some articles use an approach static in nature through signage, maps and texts whereas others reflect dynamic interactions of spoken toponyms through personal contacts.

For anyone interested in migration and integration, and in particular the geographical names used by migrants and their host society, this book provides a wide-ranging and colourful collection of articles from both a spatial and temporal perspective, illustrating how power and social relations impact the toponymic landscape. In the articles, the language of migrants is approached both synchronically and diachronically, and many examples with diverse results are provided of migrants arriving in areas sparsely named as well as areas with dense and well-established names. However, as indicated by the editors, there is a clear opportunity for further research in this subject, where toponyms provide pointers to the response of migrants to their new surroundings.

The book is of a handy and convenient size, has a pleasing cover and page layout well presented for the reader. Furthermore, the symposium proceedings include numerous interesting black and white photos, maps and tables usefully illustrating the texts. 